\title{
Urbanisation in Between
}

Rural traces in a rapidly growing and industrialising county city

Andrew B. Kipnis

\section{OpenEdition}

\section{Journals}

Electronic version

URL: http://journals.openedition.org/chinaperspectives/6238

DOI: 10.4000/chinaperspectives.6238

ISSN: 1996-4617

\section{Publisher}

Centre d'étude français sur la Chine contemporaine

\section{Printed version}

Date of publication: 1 September 2013

Number of pages: 5-12

ISSN: 2070-3449

\section{Electronic reference}

Andrew B. Kipnis, "Urbanisation in Between », China Perspectives [Online], 2013/3 | 2013, Online since 01 September 2013, connection on 28 October 2019. URL : http://journals.openedition.org/ chinaperspectives/6238; DOI : 10.4000/chinaperspectives.6238

(C) All rights reserved 


\title{
Urbanisation in Between:
}

\author{
Rural traces in a rapidly growing and industrialising county city
}

ANDREW B. KIPNIS

\begin{abstract}
This article focuses on the lived experiences of people who have moved to Zouping, a rapidly urbanising city in Shandong Province. It argues that the variety of their experiences reveals much about Chinese processes of urbanisation. Recent writing on Chinese urbanisation often portrays a sharp social break with rural experience. This article discusses the variable degrees of continuity with rural pasts that different groups of new urbanites experience. It presents Zouping as an intermediate case of Chinese urbanisation, illustrating aspects of both migrant and in situ development, and also argues for the importance of attention to divergent examples of lived experiences, which often blend or transcend the ideal types presented in models of urban experience.
\end{abstract}

KEYWORDS: urbanisation, industrialisation, social embeddedness, lived experience, family forms.

M odernisation theory emphasises the discontinuities of lived experience that occur under processes of capitalist urbanisation - the abrupt shifts in kinship practice, orientation towards community, and ways of life that urbanisation is said to bring about, giving rise to individualism, cosmopolitanism, and sometimes social alienation. ${ }^{(1)}$ Contemporary Chinese urbanisation is taking place at breakneck speed, and most recent sociological and anthropological studies of this urbanisation have been emphasising themes that resonate with this classic literature, such as the growth of individualism or the spread of anomie and alienation. Xin Liu, for example, writes about anomie in the lives of contemporary urban Chinese businessmen, (2) while a number of authors have stressed how contemporary Chinese society emphasises the individual. (3) Much of the research on such themes has taken place in China's largest urban areas, where vast waves of immigrants and migrant workers have left their village homes and some of their rural norms.

In sharp contrast, the emphasis in earlier writings on Chinese urbanisation focused on how China provided an alternative model to Western capitalist urbanisation. Martin Whyte and William Parish suggested that the urbanisation that occurred under the Mao-era planned economy, shaped by the interlinked systems of household registration (hukou), work units (danwei), and neighbourhood committees (juwei), took a different shape to the urbanisation that had occurred in Western countries. Families and neighbourhood communities remained close-knit, they argued, while crime, drug addiction, and prostitution seemed rare, and slums or shantytowns were non-existent. Everyone and everything within the urban domains that they depicted appeared to be heavily regulated and tightly governed. ${ }^{(4)}$

During the 1980s and 1990s, many authors wrote of the in situ industrialisation and modernisation (without urbanisation) that took place in postMao China with the development of township and village enterprises (TVEs) under the "litu bulixiang" (leave the soil but not the rural vicinity) model. Greg Guldin called this China's "rural urbanisation." (5) As the prominence of township and village industry faded during the late 1990s, the China studies field as a whole began to focus more sharply on large urban areas and processes of alienation and individuation, as depicted above. In this article, I offer a middle pathway between contemporary studies of urban China that are stimulated by themes from classic modernisation the- ory and earlier studies that saw China as representing an alternative model of urbanisation.

I focus on Zouping, a Shandong county capital whose population has grown from about 20,000 to more than 300,000 during the past three decades. As Beatriz Carrillo argues, the urbanisation that occurs in midsized metropolises has been an understudied phenomenon over the past decade or so. She notes that the new residents of county capitals and midsized cities often come from the nearby surrounding countryside, and thus are less dis-embedded from their "rural roots" than migrants to the Pearl River Delta or to large eastern metropolises such as Beijing, Shanghai,Wenzhou, or Nanjing. (6) Zouping in some respects resembles the Shanxi county town described by Carrillo in that much of Zouping's growth stems from local migration, but Zouping is large enough to recruit migrants from further away as well. Among the local migrants and the original populace of Zouping, there is a continuing sense of embeddedness. But alienation, the expansion of social horizons, and other social processes associated with classic modernisation theory are also apparent, especially among migrants from distant locales. The contribution of this article is to insist upon the side-by-side nature of these processes.

The author would like to thank Jonathan Unger and Ben Hillman for organising the conference for which this paper was written and commenting on early drafts. Research for this paper was funded by an Australian Research Council Discovery Grant.

1. For a summary of such theory, see Michael P. Smith, The City and Social Theory, New York, St. Martin's Press, 1979.

2. Xin Liu, The Otherness of Self: A Genealogy of the Self in Contemporary China, Ann Arbor, The University of Michigan Press, 2002.

3. Mette Halskov Hansen and Rune Svarverud (eds.), iChina: The Rise of the Individual in Modern Chinese Society, Copenhagen, NIAS Press, 2010; Yunxiang Yan, The Individualization of Chinese Society, London School of Economics Monographs on Social Anthropology, New York, Berg, 2009; Yunxiang Yan, "Introduction: Conflicting Images of the Individual and Contested Process of Individualization," in Mette Halskov Hansen and Rune Svarverud (eds.), iChina: The Rise of the Individual in Modern Chinese Society, op. cit. Yunxiang Yan, "The Chinese Path to Individualization," The British Journal of Sociology, Vol. 61, No. 3, 2010, pp. 489-512; Andrew B. Kipnis (ed.), Chinese Modernity and the Individual Psyche, New York, Palgrave Macmillan, 2012.

4. Martin King Whyte and William L. Parish, Urban Life in Contemporary China, Chicago, University of Chicago Press, 1984

5. Gregory Eliyu Guldin, Farewell to Peasant China: Rural Urbanisation and Social Change in the Late Twentieth Century, Studies on Contemporary China, Armonk, NY, M.E. Sharpe, 1997.

6. Beatriz Carrillo, Small Town China: Rural Labour and Social Inclusion, London and New York, Routledge, 2011. 


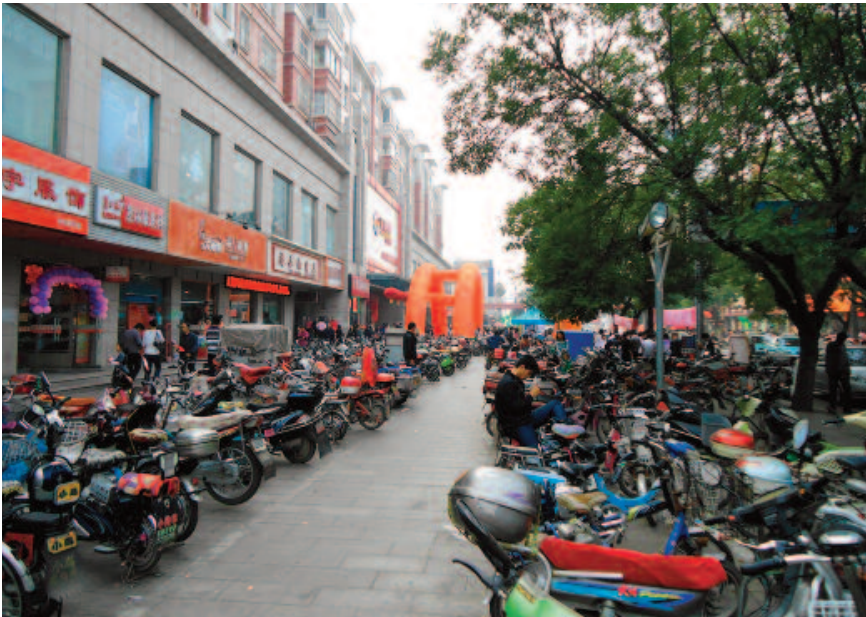

Photo 1 - Shopping street in the Old City. @ Andrew Kipnis

\section{The physical, cultural, and consumer expansion of Zouping}

During the 1990s, Zouping City grew gradually towards the north and west. But explosive growth really began after 2000, when an urban-planning specialist from Shanghai's Tongji University was invited to draw up a new plan. County leaders decided to build a "new city district" (xin chengqu) south of a superhighway that had been built in 1995 to link the two major Shandong cities of Jinan and Qingdao, and to create an industrial "development zone" (kaifaqu) east of the old city. Construction on the two new districts began in 2001, and by 2004 both had begun to take shape. The original plan for the industrial development zone entailed an additional 4.3 square kilometres of urban space, including residential areas, but the zone has been so successful that it has continued to grow and by 2010 surpassed 10 square kilometres. The new city district has likewise exceeded its originally planned size. The growth of the Weiqiao Group (Weiqiao Chuangye Jituan), a conglomerate producing textiles, aluminium, and electricity, has provided much of the economic basis for Zouping's growth. In 2009 it contributed $60 \%$ of the county's industrial tax revenue and employed more than 100,000 workers.

The movement of the county government (including the housing for officials and their families) from its previous headquarters in the centre of the old city created space in the old city for the construction of several large shopping malls and adjacent apartment buildings, turning it into a vibrant commercial district. The construction of the new city district and the expansion and revitalisation of the old city have been relatively well planned, and a pleasurable mixture of parks and public facilities, stores, shopping malls and street vendors, schools, residential buildings, and restaurants has emerged. The development zone is more polluted and has fewer parks and public spaces, but has a fair number of schools and food shopping options along with two shopping malls. A new convenient set of seven bus routes links the three parts of the city.

Alongside the growth of employment opportunities spurred by the Weiqiao industrial conglomerate and the physical growth of the urban built area has come a rapid growth in consumer spending and lifestyle changes that especially affect the young and relatively well-off. Eating habits, for example, have become more sophisticated. Rather than using the still existing but noticeably run-down outdoor markets, which sell locally-produced foods, many Zoupingers now do most of their food shopping at large su-

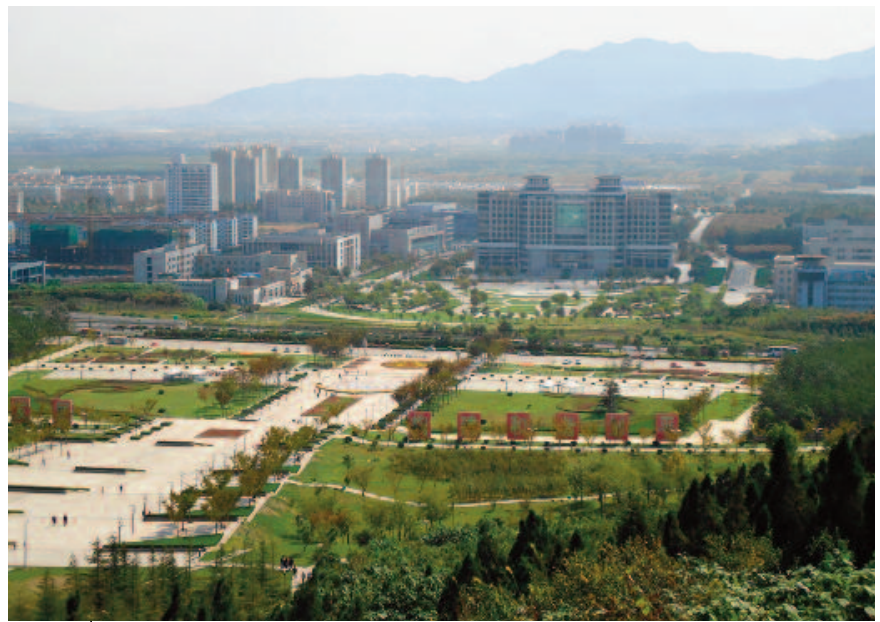

Photo 2 - New City District. @ Andrew Kipnis

permarkets (branches of province-wide chains), which sell food from all over the country (and even the world). During the 1980s, everyone I knew in Zouping ate mantou (steamed bread) three meals a day seven days a week. While mantou is still the staple food of the region, it now is widely supplemented with noodles, rice, dumplings, bread, soy milk, dairy products, and other staples. Eating out at restaurants has also become commonplace. During the 1980s there were a few restaurants, but now there are hundreds and a great many smaller food stalls. They serve dozens of food types: Sichuan food, Shanghainese food, Yunanese rice noodles, Mongolian hot pot, donkey meat, Cantonese food, Brazilian barbeque, Xinjiang barbeque, Halal (Muslim) meat noodles, Taiwanese soy milk, Kentucky fried chicken, California-style Chinese food, etc. Over the past five years, numerous "countrystyle" restaurants (nongjiale) have sprung up, indicating that at least some of the newly urbanised residents of Zouping feel nostalgia for their rural roots. In short, food culture in Zouping is becoming more cosmopolitan, less local, and decidedly "urbane."

While in the past there was only one main department store in Zouping and one clothing market, now there are hundreds of clothing stores and at least a half-dozen major department stores. During the 1980s all of the clothing in Zouping was of inexpensive varieties. Now some stores offer clothes that are pricey even by Western standards, with US\$100 shirts and US\$1,000 suits. Especially on Friday and Saturday nights, street life in many parts of the city has become vibrant. On the main avenues of the old town, in the pedestrian mall of the new city district, and in front of the main shopping centre of the development zone, hawkers abound after dusk, and stores blast music from their shop fronts. Some businesses even set up stages on the sidewalk with talent shows of "beautiful girls" (meinü) singing and dancing. In addition to bustling restaurants and teahouses, patrons entertain each other at karaoke clubs and bars into the wee hours of the morning, especially in the "all-night district" (buye cheng) of the new city district. The development zone contains roller-skating rinks, Internet bars, and pool halls catering to single migrant workers. In many parts of the city the atmosphere is "hot and noisy" (renao), to use the Chinese phrase for lively, festive places.

The types and breadth of consumption in Zouping reflect a felt shift in local perspectives toward a national focus. That is to say, people pay extra to consume the food of other parts of the country, take trips to other parts of the country, educate their children in preparation for the national uni- 


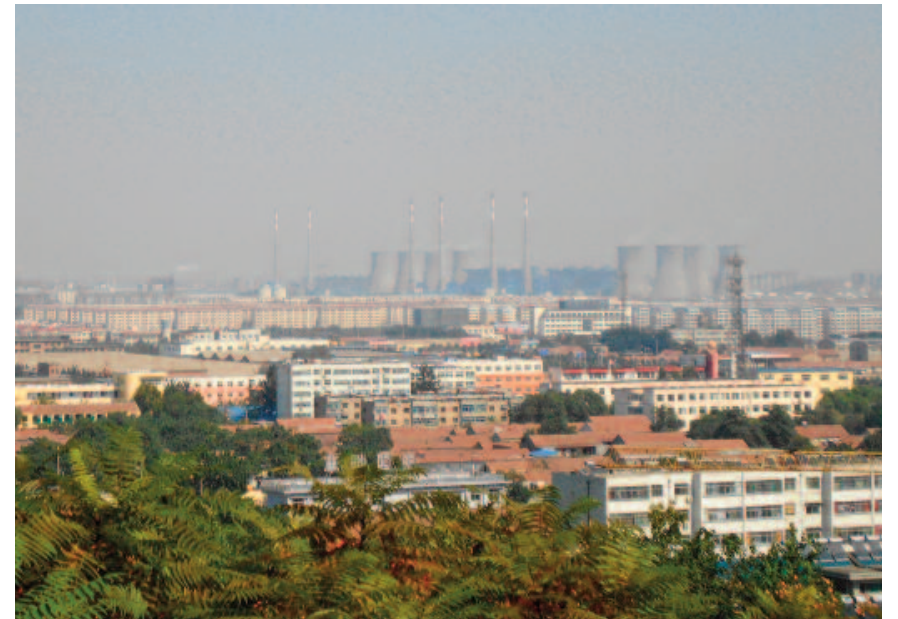

Photo 3 - The development zone. ๑ Andrew Kipnis

versity entrance exam, and come to imagine their futures in terms of urban and new national lifestyles. ${ }^{(7)}$ This outreach does not entail a repudiation of the local, however. As Zouping has prospered, a new sense of local pride has emerged. Even as young people learn how to speak Mandarin in a standard national way, pride in the local dialect is being reasserted, and local identities - notions of being a bendiren, a native resident - are becoming more important. Moreover, the attractiveness of a "hot and noisy" atmosphere and country-style restaurants can be seen as tastes reflecting an ongoing rural habitus. ${ }^{(8)}$ In short, as much as Zouping's in-migration and urban lifestyle can be seen as taking people away from their families and out of the local community, they also are involved in the reproduction of families and the reassertion of community. This same local/non-local dynamic applies to urbanisation's usual twin: industrialisation.

\section{The economic roots of Zouping's growth}

The Weiqiao industrial conglomerate had previously been headquartered in the town of Weiqiao, which is in the northwestern part of the county, roughly 30 kilometres from the county capital, where it retains some of its cloth production. After the opening of the development zone, most of its facilities were relocated to the county capital, where the company became a magnet for employment. The history of this corporate group demonstrates the relatively indigenous and organic nature of industrial development in Zouping. It began as a collectively-owned enterprise in Weiqiao during the 1980s. In that period there were literally hundreds of similar small-scale publicly-owned rural township and village enterprises (TVEs) scattered across the towns and even the 800 or so villages of the county. Zouping County had long been a cotton growing region, and cotton spinning and cloth manufacture were the first industries attempted by the village government entrepreneurs who emerged during that period. Weiqiao's founder and current CEO, Zhang Shiping, proved quite resourceful in purchasing appropriate machinery, motivating workers and hiring outside experts to overcome production difficulties, and gradually out-competed all of the other cloth-producing TVEs in the county. Almost all of these TVEs went bankrupt, and the county government threw its support behind this winner. As Zouping was a large agricultural county, Zhang believed that it had a nearly endless supply of labourers happy to work in cloth factories. Although he could be a ruthless businessman, and although he amassed a personal fortune

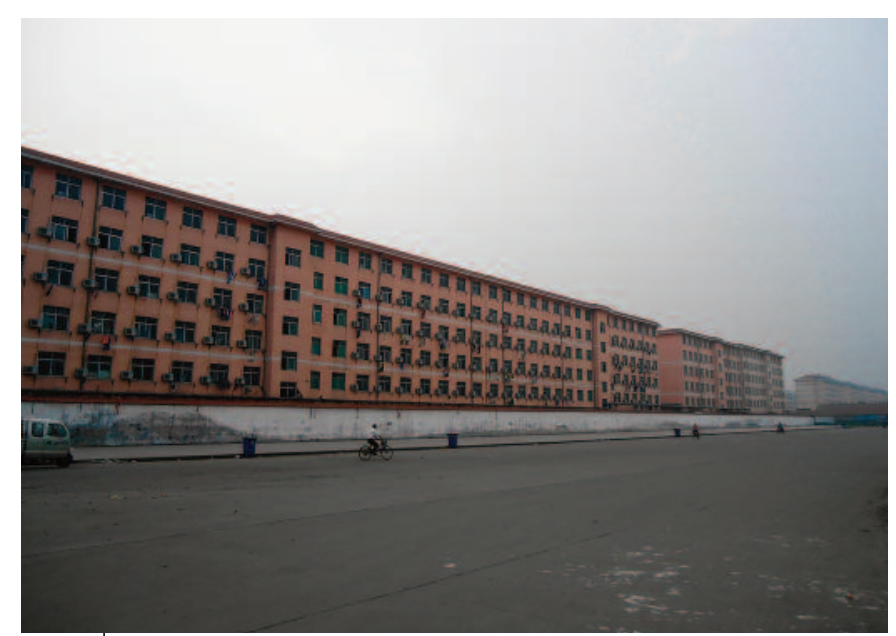

Photo 4 - Dormitory rooms for Weiqiao workers. @ Andrew Kipnis

when the business was privatised with himself and his family members as the leading shareholders, his dedication to providing employment to Zouping residents and the moral capital this commitment gave him in his dealings with the county government can be seen in the Group's title, which literally translates as The Weiqiao Employment Creation Group.

The fact that Weiqiao was based on the idea of providing employment for workers from the surrounding area rather than exploiting migrant labourers from far afield has given Weiqiao a more humane feel than many of the factories in South China's Pearl River Delta. While work in Weiqiao is strenuous for its contract (hetong, relatively permanent) workers, the pay is reasonable and the benefits are many. For the unmarried, there are free dormitory beds in rooms with heating during the winter and (since 2009) air conditioning in the summer. There are more than 20,000 subsidised apartments for sale to married contract workers, and these come with heavily discounted utilities and nice recreational facilities. There are numerous other minor benefits that make Weiqiao seem more like a socialist-era work unit (danwei) than a typical twenty-first century Chinese factory. ${ }^{(9)}$ In addition, the Weiqiao Group gave the county education bureau the money to build two completely new schools in the development zone near the company's housing compounds. These schools have truly excellent facilities and are attended primarily by the children of factory workers and of families from the villages whose land was requisitioned to build the industrial zone. Some workers say that the reason they chose to work at Weiqiao is because of the quality of the schools available to their children.

Though the second largest business group in Zouping County is considerably smaller, its history is quite similar. The Xiwang Group is headquartered in Handian, a town just north of the county seat. As a result of its success, along with the expansion of the old city, Handian and Zouping City have now become one contiguous urban area, and there is even a city bus route that takes many workers from Zouping City to their jobs at Xiwang. Xiwang also started as a TVE but it specialised in making corn oil, cornstarch, and later high-tech bio-products from corn. Corn is also a traditional crop in the

7. Andrew B. Kipnis, "Chinese-Nation-Building as, Instead of, and Before Globalization," ProtoSociology, Vol. 28, 2011, pp. 25-48.

8. On renao in a rural context, see Chapter Seven of Adam Yuet Chau, Miraculous Response: Doing Popular Religion in Contemporary China, Stanford, Stanford University Press, 2006.

9. For another case of work-unit-like factories in the twenty-first century see Anita Chan and Jonathan Unger, "A Chinese State Enterprise under the Reforms: What Model of Capitalism?", The China Journal, No. 62, 2009, pp. 1-26. 
area, and many Zouping County TVEs specialised in products processed from corn during the 1980s. Like Weiqiao, Xiwang out-competed its rivals to become the dominant corporation in its industry. It has successfully moved into product lines requiring considerable technological sophistication and has thrived by employing outside experts, especially in bio-chemical engineering, while drawing on the local population for more mundane jobs. It too offers its permanent employees housing and a host of other benefits and in many ways operates like a socialist-era work unit. Like Weiqiao, it has funded the rebuilding of local schools so that its employees can be assured of excellent education facilities for their children. These schools have been a crucial factor in the ability of Xiwang to recruit highly educated experts from other places in China.

But understanding Zouping as an alternative to typical capitalist (and much of China's current) urbanisation is too simple. Despite the workunit like employment opportunities and the local origins of many of the workers and of the industries themselves, some aspects of Zouping's development resemble the exploitative patterns of work that emerged in the Pearl River Delta. Weiqiao in particular employs a large number of migrant workers from outside of Zouping and Shandong. Many of these are "temporary" (linshi) rather than "contract" (hetong) workers. They are not eligible to purchase work unit housing and often end up renting shabby rooms in the still-existing villages on the outskirts of the development zone, which have grown into high-density, unsanitary shantytowns. As in many parts of China, Zouping residents who do not work at Weiqiao and who live away from the development zone often give voice to prejudicial sentiments about migrant workers being people of low "quality" (suzhi) and having criminal tendencies. ${ }^{(10)}$ Among local people, there is also a growing disdain for factory work. I have spoken to many young people from Zouping who complain that labouring at Weiqiao is too hard and bitter and that they would much rather accept a lower paying, less permanent job in the service sector, though there are still Zouping residents entering the factories. As in the Pearl River Delta, some of the villages whose land lies next to the factory zone have become relatively wealthy, and there is a noticeable divide between these local villagers and outside migrants in terms of wealth if not in terms of education levels and social outlook. This divide, however, has not reached the extremes in the Pearl River Delta described by Chan, Madsen, and Unger. ${ }^{(11)}$ In short, while it would be inaccurate to say that the divide between migrants and locals maps directly onto the divide between Weiqiao factory workers and those who work in other vocations, it would also be wrong to say that anti-migrant prejudice is absent or that locals do not try to distinguish themselves from migrants by finding work outside of the hardest, most exploitative forms of industrial production.

Whereas Zouping's industry was earlier based on local agricultural inputs, the industrial activities of Weiqiao and Xiwang are increasingly driven by a search for high profit margins rather than the ability to locally source agricultural products. In fact, with the further development of Zouping's and China's transport system, Weiqiao has stopped sourcing its cotton locally, obtaining most of it from Xinjiang. The county government has encouraged Weiqiao (along with a few other local corporations) to go into aluminium refining because it is an industry that offers relatively high profit margins (if one accepts the high levels of air pollution and accident risk that come with it). While most of Weiqiao's workers remain in cloth production, more and more of its profits are coming from aluminium refining.

\section{Lived experiences}

The diverse outcomes of urbanisation and industrialisation in Zouping can be illuminated through a series of family portraits of Zouping residents in the midst of a transition from non-industrial and rural backgrounds to an urban setting: long-term contract workers, migrant workers, people who profit as landowners in Zouping's "villages in the city" (chengzhongcun), youths who refuse to work at Weiqiao, and youths who hope to work there. Interviews with more than 250 individual residents or households reveal that each of the households or people that I will depict here is typical of a significant subsector of this population. These portraits enable us to glimpse the ways that lived experiences bridge or do not bridge the rural/urban and the alienated individual/embedded familial divides.

\section{Long-term contract workers}

I have spent a considerable amount of time at the schools near Weiqiao's married housing compounds and have had the opportunity to interview three dozen families who live there. Because buying a house in the factory's compound requires contract-worker status, and because the act of buying the house itself indicates a relatively high degree of commitment to and trust in Weiqiao, the workers in this housing tend to have worked at Weiqiao for a number of years and to come from villages within Zouping County, and plan on spending the rest of their lives working for the company. They are largely satisfied with their jobs and scoff at young people who complain that work in the factory is too bitter. Other long-term contract workers have chosen either to purchase housing on the open market or to live in their village homes and commute daily rather than purchase the subsidised Weiqiao housing (which must be sold back to Weiqiao at its purchase price when the worker dies or leaves the company). In either case, most contractworker families live lives that complicate the rural-urban divide and that go against notions that urbanisation gives rise to individualism, the demise of extended families, and dis-embedding from local communities.

Contract worker family A:This married couple came from villages in Matou (a township adjacent to Weiqiao), where they were born in the late 1970 s. The wife began working in cotton spinning in 1992 back in Weiqiao Township after graduating from junior middle school. The husband joined the army in 1994, but came back to the village and began working in Weiqiao in cloth manufacturing in 1998. They knew each other in junior middle school, but were reintroduced at a factory dance and married in 2000. Their only son was nine at the time of my interview in 2011. They were ordered to move to Zouping City by the company in 2005 . They were originally reluctant, because the company housing was more expensive in the county capital than in Weiqiao, and they lost a bit of money through buying and selling their company apartments, but now they are glad they did because the schools are better in Zouping. The wife works rotating shifts (lunban), six eight-hour shifts per week including day, evening, and night shifts and earns 2,800 yuan per month, while the husband works five day shifts a week (changbaiban) and earns 2,400 a month. The paternal grandparents take turns living with them and taking care of their son. The grandparent not with them lives back in the Matou village where there are many relatives

10. See, for example, Shukai Zhao, "Criminality and the Policing of Migrant Workers" (Andrew Kipnis trans.), The China Journal, Vol. 43, 2000, pp. 101-10.

11. Anita Chan, Richard Madsen, and Jonathan Unger, Chen Village: Revolution to Globalization, third ed., Berkeley, University of California Press, 2009, Chapter 15. 
and do a bit of farming. The husband also sometimes goes back to the village on the weekend, about a 50-minute drive, to help his parents with farming their land (only the two grandparents still have land rights). The wife visits her own natal family back in her Matou village at least once a month. They own a car and a motorbike and have taken vacations to the ocean in Qingdao. Their son attends after school homework classes and the parents hope he can attend university. While consumption and education expand this family's horizons well beyond the local level, tight links to extended family members and village farming ensure their continuing embeddedness in the local community.

Contract worker family $\mathrm{B}$ : The six members of this family (paternal grandfather, paternal grandmother, husband, wife, elder daughter, younger son) live in a village about a 15-minute motorcycle ride away from the county capital. The husband is a long-term contract worker in cotton spinning. Because he is adept in machine repair and works rotating shifts, he earns over 3000 yuan a month. He sometimes sleeps in one of the dormitory rooms where he has reserved a bed (at no charge to him), but only if time between shifts is tight or if he has business that keeps him in town. Otherwise he goes back to his village home every night. His wife and mother farm the land and the kids go to primary school (and kindergarten) in their township. Grandfather sometimes farms and sometimes does some "small business" (maimai). They own a car and a motorcycle, and have taken vacations in Qingdao and Beijing. Going to the local school ensures a higher degree of continuing embeddedness than in the first case, and this household has all three generations living under one roof.

\section{Migrant workers}

The situations and attitudes of migrant workers are much more diverse than those of the long-term contract workers of local origin. While some migrants manage to become contract workers, they live too far from their rural homes to also be part-time farmers, and hardly ever live in three-generation households. Because of the schools, many married workers bring their children with them, but hardly any bring their aging parents. Most return to their original homes only once or twice a year. Their attitudes towards Weiqiao and Zouping vary. Some like the place and the company and hope to move there permanently, others dislike both and are looking to leave, while some see Zouping as a reasonable but temporary home.

Migrant worker family A: This family of three (husband, wife, 11-year-old son in 2010) came to Zouping from a poor rural area in Gansu Province in 2008. The husband went to a technical school (zhong zhuan) and is an electrician. They came to Zouping because of his younger brother, who had gone to university, graduated in engineering, entered mid-level management in Weiqiao, and married a local Zouping woman who is a teacher. When the older brother and his family first arrived in Zouping he worked as an electrician repairing faults in one of Weiqiao's housing compounds. After a year he quit to start an electric repair shop in a shopping centre in the development zone, as his job in the housing compound had exposed him to a high level of demand for repairing TVs and other appliances. The family lives in one room in the back of the store without a proper kitchen or toilet. They use the public toilets in the shopping centre. They are saving all of their profits from the shop in the hope of one day buying a private apartment (in 2010, private apartments in the development zone started at about 200,000 yuan for 80 square metres; a subsidised Weiqiao apartment of the same size was about 80,000 yuan). The younger brother has gone back to Gansu to visit his parents, but neither husband nor wife has been able to afford the trip back since first coming in 2008. Though quite divorced from their rural roots, this couple relied on familial connections to come to Zouping.

Migrant worker family B: This family of three (husband, wife, 11-year-old daughter) are from a village in Zaozhuang Prefecture (south central Shandong near the jiangsu border). Since 2003, they have rented a room in an adobe village house near the development zone for 120 yuan a month. When they first came to Zouping they worked for Weiqiao in cotton spinning, but couldn't stand the heat (in cotton spinning the temperature is maintained at 40 degrees centigrade year round) and found work in a smaller factory group at slightly less pay. They both work rotating shifts for seven 8-hour shifts a week; the husband earns 3,000 yuan a month and the wife 2,000. They are saving all their money to buy an apartment. They think they will have enough for a $50 \%$ down payment and a $50 \%$ mortgage in a couple more years. The wife hopes to have a second child in the next year or so. "When our younger child is one year old and our older daughter starts junior high school will be the perfect time to buy an apartment."

They return home twice a year (a ten-hour bus trip). Their home district is much poorer than Zouping. The paternal grandparents have only 2 mu of land to farm (a third of an acre), as the population-to-farmland ratio is much denser there. The younger couple say that they have a nice house back home, where it is less polluted, but Zouping offers better employment opportunities and better schools. Although the current high savings of this family's members keeps them from participating in most of the consumer society that Zouping offers, they will have opportunities for more consumption once they manage to buy their own home. This couple is quite nucleated. Other than occasional visits to the husband's parents, they have dis-embedded from their home community and focus all of their efforts on their own social advance.

Migrant worker family C: This family of four (husband, wife, 11-year-old daughter, 4-year-old son) comes from Heze, the poorest prefecture in Shandong in the southwestern corner of the province. The couple both work at Weiqiao. The husband is a contract employee in cotton spinning making 2,600 yuan a month doing rotating shifts, while the wife just started at day shifts as a temporary employee earning 2,000 per month. She didn't work from the birth of their son until he was old enough to go to kindergarten. When the wife gets too busy with her work and shopping, the elder daughter has to take care of her younger brother and walk him home from kindergarten. Although the husband is eligible to buy Weiqiao housing, he does not want to. The company housing can't be resold on the open market and the "owners" don't even get an owner's certificate (fangchan zheng), he said. "Who could trust Weiqiao? They say you can get your money back if you move out, but we don't feel comfortable with that." For 200 yuan a month, the family rents two shabby rooms in an overcrowded village on the outskirts of the development zone. The husband said that he didn't really like it in Zouping and that similar employment opportunities were available in many mid-sized Shandong cities, but that Zouping had the best schools of the places he had heard about. He added that in future, when his son is in junior middle school (and daughter in university), he would put his son in one of the school's dormitories and move back to Heze with his wife. "We have a nice house there and it is more comfortable to live near friends and family." This family endures alienation in Zouping in the hope that their children will one day attend university. Future plans involve re-embedding in the home community. 
Single migrant worker (female): This woman was 23 and came from Dezhou, a poorer prefecture in northwestern Shandong. She has an older brother and younger sister, but their father left them when they were young and she was raised by her mother alone. "Do you know what it means to be a 'single parent' (danqin jiating) in the countryside?" she asked rhetorically. She came to Zouping eight years ago when she was 15 and managed to get a job spinning cotton, despite not having finished junior middle school (management told me they only hire junior middle school graduates). She has always been a "temporary worker," and she always dreams of leaving. She said she dislikes working at Weiqiao - it is too hot and noisy and tiring - but that she is desperate because of the poverty of her family. She lives in a dorm room and said that it took a long time to make any friends. She hopes one day to move back to Dezhou and marry someone in her hometown.

Single migrant worker (male): He came from the neighbouring city of Zibo four years earlier when he was 19. In 2010, he made 2,000 a month working seven days a week in one of the smaller textile companies. He said that the money was alright, but that he was always tired and that he had to work seven shifts whenever management required if he wanted to keep his job. He lives in a dorm and hasn't thought much about marriage yet and doesn't know whether he would rather settle in Zouping or move back to Zibo. He said, "Overall, my situation isn't good. To make money I have to take a job I hate. If I move back home, I won't make money and I'd never have a family (chengbuliao jia)." For both of these workers, hopes of forming a family cause them to endure considerable alienation and loneliness. How much community embeddedness the future will bring is an open question.

\section{Villagers in the city}

As Zouping has expanded over the years, there has been a wide variety of conditions under which villagers have had their land requisitioned, but almost all have ended up better off than villagers who did not. Although the process has become more regulated over the past decade, even many of the villagers who had their land requisitioned during the 1990s are doing well. Here I focus on people from villages that had their land requisitioned since 2001, and those who live in the development zone rather than the new city district. Some villagers have had both their farmland and original houses requisitioned and have been moved into new apartment complexes. Other villagers have only lost their farmland, but continue to live in their original houses. The most fortunate live close enough to the factories and schools that they can earn significant money renting rooms to migrant workers, and some of these villages have seen a quasi-illegal private construction boom of rental housing even though their villages are slated for eventual destruction (chaiqian). Some villages have seen their population grow from less than 1,000 to more than 10,000 and are filthy, with sewage running out from overflowing public toilets and showers and garbage piles strewn around empty lots.

Villager-in-the-city household A: This family lives in the dirtiest and most populated rental village - but they have had considerable luck. There are seven people in this family: two paternal grandparents, husband, wife, an elder daughter who was 11 in 2011, and a twin pair of one-year-olds. They are the first Zouping couple I have met who legally have given birth to three children. For the first 30 years after their land was requisitioned in 2007, they will receive roughly 2,800 yuan per household member per year as "dunliang qian" (money for their loss of agricultural income, the total coming to about 20,000 yuan in 2010 for their household). (12) They have built 18 cheap and shabby rental rooms on top of and around the seven very well-built and outfitted rooms they reserve for themselves in their courtyard house. The rental rooms were full and rented for 100 yuan a month each in 2010 , so the family had a second source of approximately 20,000/year in income without working. The husband and wife also ran a clothing business selling mostly to migrant workers. They started off with a stall earning 23,000 yuan a month, but now have rented a shop and earn between 5,000 and 10,000 a month. The grandparents look after the children and cook. They own two cars. The parents only graduated from junior middle school, but this family now has a total income of considerably over 100,000 yuan a year. As an extended family, they remain in the community where the grandparents, parents, and children were born. As with most villager-in-thecity households, their community embeddedness is high.

Villager-in-the-city household B: This family of six lives in Beifan, a village that had its agricultural land requisitioned but which, as of 2011, was too far from the schools and factories to attract a significant room-rental business. The six family members include the paternal grandparents, husband, wife, an elder daughter in senior middle school, and an 11-year-old in year five in 2011. In 2010 they received 17,000 yuan in dunliang gian. The couple both stopped school after junior middle school. The husband makes 3,000 a month working for a construction sub-contracting team organised by a village leader, while the wife makes 2,000 yuan a month working rotating shifts at Weiqiao. The grandparents retired after the family lost its farmland. As in many such cases, the grandparents use their newfound leisure time to help with the children and maintain ties to other households in the community.

Villager-in-the-city household C: This household comes from a village that has lost both its land and housing, though the village has a collective income stream from the former collectively-owned land. They live in a beautiful 150-metre square apartment in a compound that combines residents from their former village with those of two others. They bought the apartment in 2010 at the subsidised price of about 150,000 yuan. They estimate that it was worth about 350,000 yuan at 2011 market prices. They also receive free electricity and water as a result of the income their village receives from its collective real-estate holdings. With three household members, they received 10,000 yuan in 2010 in dunliang qian. The wife has taken a job as a saleswoman in the ritziest department store in the old city. She makes 800 yuan a month plus commissions, which vary between 500 and 1,000 a month. Her husband drives an unregistered taxi (heiche) and can make about 2,000 a month. He said that they were too comfortable to put up with factory work, and had selected occupations that give them relatively relaxed lifestyles. Though living as a nuclear family, the participation in village income streams and residence in a village apartment building suggest ongoing community ties.

\section{Factory work and Zouping's future}

Zouping's fate as a future community rests upon people committing to factory work. Here I briefly explore attitudes towards factory work among young people.

\section{Youths who dislike Weiqiao}

I have spoken with many single young people who have made a conscious choice to work as service personnel in Zouping's hotels, restaurants, and

12. The exact amount depends upon the market value of grain (wheat) on 31 July of each year and the total number of eligible recipients in the household and village as a whole. 
shops. They know they could earn more money working at Weiqiao or one of the other factories, but they see such work, particularly at Weiqiao, as undesirable.

22-year-old single man from Zouping: He has a chemical engineering degree from a short course university. He works as an art teacher for children at a local art studio and makes about 1,600 yuan a month. He said that chemical engineering jobs in the local factories are dangerous. One of his classmates had already died in an explosion and another had suffered second-degree chemical burns on his face in a separate incident. He said the most profit-making industries were the most dangerous, as money was made by cutting corners on safety regulations and then compensating workers after accidents. In an infamous accident at Weiqiao's aluminium refinery in 2008, about a hundred workers died when one of the boilers exploded. He said he would never work for Weiqiao, no matter how good the pay, as it was too dangerous.

20-year-old single man from Hebei: He arrived in 2009 to work in Weiqiao, but quit after two months. He couldn't stand the heat and noise in the cotton spinning plant and in 2010 earned 1,100 yuan a month working as a doorman in a hotel. He said, "Earning money isn't everything, I have to live my life. If work is torture then how can you continue? Now I feel free. I think I will go to Shanghai soon and try my luck there."

\section{Youths looking for factory work}

Despite the negative opinions of some, there are still youths interested in working at Weiqiao and other nearby factories. The Zouping government has been helping the factories to recruit employees through its own technical school (zhiye xueyuan), which runs courses in whatever majors the local business groups demand. If the groups sign contracts agreeing to recruit a certain number of graduates, the technical school will recruit students from outside of the county. It has regular recruiting relationships with other prefectures in Shandong as well as Gansu, Hebei, Henan, and Hunan provinces. I joined a machine electronics class for a week and briefly interviewed all 34 members of that class, of whom 29 were male and 5 were female; 16 were from Zouping, 11 from other Shandong counties, and 7 from other provinces. While some of the non-locals hoped to find factory work in their hometowns, most of the Zouping students were aiming to get work in Zouping factories. They almost all grew up in villages and disliked academic schooling.

17-year-old boy from a Zouping village: He hates regular school, but likes fiddling with electric machines, so this major is good for him. His father works at Xiwang while his mother farms. He hopes to get a job at one of the factories in the development zone. He said the pay is good there - over 2,000 yuan a month.

17-year-old girl from a Zouping village: Her father is a temporary worker in Weiqiao and her mother farms the land. Her ideal is to become a doctor, but she did not do well enough on the senior middle school entrance exam to get into a senior middle school without paying an extra fee, so now her hope is to work for one of the larger factories in the county capital. She said this would be better than farming and that living in the county capital is better than living in a village.

16-year-old-boy from the neighbouring city of Zibo: His parents originally came from a rural county in northern Shandong, and then found factory work in Zibo. His parents were laid off from their jobs in Zibo and have found work as temporary employees at Weiqiao. He lives with his parents in a rented room in Zouping, but considers home to be the village in northern Shandong, where his paternal grandparents still have farmland. He said he picked his major because his parents told him that it was easy to find work. He would like to be a contract worker in a factory in Zouping, doing electrical repairs.

\section{Urbanisation and people in transition}

The co-presence of the disparate groups that have been depicted here illuminates much about the patterns of urbanisation in the county. Many conclusions may be drawn. In situ urbanisation certainly makes a difference. When a significant portion of the rural population does not have to travel far from home to secure industrial employment or to live in a place large enough to be called a city, forms of living that blur the divide between rural and urban, agricultural and industrial become possible. Regardless of the extent to which they live together or share a common budget, extended families can work together to raise children, pursue diverse economic opportunities, and care for sick members. Social networks flourish, and information about job opportunities and about the various advantages and disadvantages of town and village living can travel quickly. Agriculture can be undertaken as a part-time activity rather than fully abandoned. Finally, local governments and employers treat workers better, as a type of recognised constituent, if they see them as locals.

Yet there are limits to the difference in situ urbanisation can make, at least within a marketised economy. The companies that form the backbone of the Zouping economy cannot offer employment conditions that price their products out of the marketplace. A certain percentage of temporary workers must be used so the company can easily shed salary burdens during periods of economic recession. The harshness of factory discipline cannot be relaxed, and measures to improve work comfort or safety outstripping those of competing companies cannot be implemented.

To the extent that places such as Zouping are economically successful, they attract increasing numbers of outside migrants. If large companies can offer employment that is better than in other cities, or the schools are better and real estate prices are lower, they will attract migrants. If living standards progress to the point that locals will not put up with the bitterness of factory work, then companies take measures to recruit migrants. Both of these factors are apparent in Zouping. While Zouping has not exhausted the supply of local villagers willing to work at factory jobs, migrant workers are taking an increasing percentage of them. Migrant workers are more likely to be single or to live in nuclear families, become dis-embedded from their home communities, and are more likely to experience anomie and alienation.

I can imagine many possible futures for Zouping, but continuing economic prosperity seems to require continuing supplies of factory workers. As shown above, perceptions of the desirability of factory work tend to vary with age. But is this difference best understood as generational or as a life-stage difference? That is to say, are the youths who dislike factory work likely to change their minds once they marry and have children, or is their distaste for factory life a matter of being brought up in a different era and thus a relatively permanent aspect of their outlook? On the one hand, it is clear that, overall, Zouping's youths are becoming better educated. Will university graduates be willing to work in factories alongside technical school graduates? On the other hand, it is quite clear that working in factories near to home has advantages over becoming a migrant worker, especially when one 
has children to raise. Will the lure of finding employment close to home outweigh aversion to factory work?

The more competitive the education system becomes, the more it guarantees a steady stream of students who hate academic life and either drop out of school or daydream their school time away. In addition, Weiqiao attempts to overcome aversion to difficult work with its wage structure. It purposefully pays higher wages to employees who undertake difficult jobs rather than automatically giving white-collar or pink-collar workers higher wages than bluecollar workers. I have no way of answering questions about the future desirability to local people of blue-collar work, but if in the future most new urban migrants and industrial workers come from outside the county, then Zouping may lose its distinctiveness as a site of in situ industrialisation.

Earlier in this article, it was observed that among the more affluent strata of households of Zouping City, urbane lifestyles have emerged both because of the intersection of relative wealth and consumption opportunity and because of the types of competitive consumption that develop within embedded social relations where many families are becoming more wealthy. This urbane consumerism is quite alien to the cramped lifestyles of some of the people whose profiles I have just presented. The co-presence of multiple forms of urban experience is a common circumstance. In part it is the multiplicity of the present that makes for the possibility of multiple futures. One way of thinking of urban transformation is not to portray it as the obliteration of old forms of life but as the simultaneous creation of new spaces and possibilities alongside the continual reinvention of the old. Cosmopolitan consumption, alienated youth, and shanty-towns on the urban fringe seem relatively new, at least in their extent. Yet, old lifeways, family forms, economic and political relationships, and patterns of thought (though transformed), somehow remain recognisable. In Zouping, we still see extended families, consumer tastes related to a rural habitus, small-scale farming, and the dynamics of finding meaning through familial sacrifice long after Zouping has been transformed from a town into a city.

\section{Andrew B. Kipnis is Professor of Anthropology at the Australian} National University.

College of Asia and the Pacific, The Australian National University, Canberra ACT 0200 (andrew.kipnis@anu.edu.au). 